\title{
Artikel
}

\section{Selectieve distributieovereenkomsten: het luxepaardje van de onlineverkoper?}

\author{
Elske Raedts en Felix Roscam Abbing*
}

We consumeren steeds meer online. In 2015 gaf de Nederlandse consument ongeveer 16 miljard euro uit aan onlineaankopen en naar verwachting zal dit bedrag in 2018 oplopen tot bijna 25 miljard euro. ${ }^{1}$

Zoals de Europese Commissie (hierna: Commissie) opmerkt in haar Eindverslag over het sectoronderzoek naar e-commerce (elektronische handel in consumptiegoederen en digitale inhoud) (hierna: het Eindverslag), ${ }^{2}$ heeft e-commerce niet alleen een aanzienlijke impact gehad op klantgedrag, maar ook op distributiestrategieën van ondernemingen in de EU. E-commerce heeft geleid tot prijstransparantie, prijsconcurrentie en het makkelijker bereiken van klanten, bijvoorbeeld via onlinemarktplaatsen.

De Commissie merkt op dat fabrikanten proberen meer controle te krijgen over distributienetwerken, prijs en kwaliteit van de goederen die zij verkopen als reactie op de grotere prijstransparantie en prijsconcurrentie. Volgens de Commissie leidt dit onder meer tot een toename van verticale beperkingen tussen fabrikanten en retailers. De Commissie neemt bijvoorbeeld een toename waar in intra-merk concurrentie doordat fabrikanten via het internet hun producten steeds vaker direct aan eindgebruikers aanbieden. Daarnaast neemt de Commissie waar dat fabrikanten steeds meer beperkingen opleggen ten aanzien van verkoop en informatiever-

Mr. E.N.M. Raedts is werkzaam als advocaat bij Freshfields Bruckhaus Deringer. Mr. F.A. Roscam Abbing is werkzaam als advocaat bij Freshfields Bruckhaus Deringer. De auteurs danken Maxine Lemstra voor haar bijdrage aan dit artikel.

1. Zie https://ecommercenews.eu/ecommerce-per-country/ecommercethe-netherlands/.

2. Verslag van de Commissie aan de raad en het Europees Parlement van 10 mei 2017, 'Eindverslag over sectoronderzoek naar e-commerce', COM(2017)229 final (hierna: Eindverslag). schaffing via het internet (zoals prijsbeperkingen, een marktplaatsplatformverbod, beperkingen inzake het gebruik van prijsvergelijkingstools en de uitsluiting uit distributienetwerken van louter online opererende marktspelers), al dan niet in combinatie met het gebruik van 'selectieve distributiestelsels'.

Ten tijde van het Eindverslag was een prejudiciële zaak hangende bij het Hof van Justitie die hier mogelijk een verdere invulling aan zou geven; zaak C-230/16, Coty Germany GmbH/Parfümerie Akzente GmbH (hierna: Coty). ${ }^{3}$ In het onderstaande artikel zullen wij aan de hand van nationale en Europese rechtspraak - en in het bijzonder de Coty-uitspraak van 6 december 2017 ingaan op de vraag wanneer een (online) marktplaatsverbod mededingingsrechtelijk toelaatbaar is.

\section{Het wettelijk kader voor selectieve distributie- overeenkomsten}

De Verordening betreffende de toepassing van artikel 101, lid 3, van het Verdrag betreffende de werking van de Europese Unie op groepen verticale overeenkomsten en onderling afgestemde feitelijke gedragingen (hierna: de Groepsvrijstelling Verticalen) ${ }^{4}$ en de Richtsnoeren inzake verticale beperkingen (hierna: Richtsnoeren Ver-

3. HvJ EU 6 december 2017, zaak C-230/16, Coty Germany/Parfümerie Akzente, ECLI:EU:C:2017:941.

4. Verordening (EU) nr. 330/2010 van de Commissie van 20 april 2010 betreffende de toepassing van artikel 101, lid 3 VWEU op groepen verticale overeenkomsten en onderling afgestemde feitelijke gedragingen, PbEU 2010, L 102/1. 
ticalen $)^{5}$ vormen een leidraad voor het beoordelingskader van verticale afspraken onder artikel 101 lid 1 Verdrag betreffende de werking van de Europese Unie (VWEU). Wanneer een afspraak wordt vrijgesteld van toepassing van artikel 101 lid 1 VWEU op grond van een EU-groepsvrijstelling (bijv. de Groepsvrijstelling Verticalen), is de afspraak ingevolge de artikelen 12 en 13 Mededingingswet $(\mathrm{Mw})$ eveneens vrijgesteld van toepassing van artikel 6 lid $1 \mathrm{Mw}$, ongeacht of deze gedraging een grensoverschrijdend element heeft of niet.

In het Eindverslag concludeert de Commissie dat een absoluut marktplaatsverbod (ongeacht of het onderdeel is van een selectief distributiestelsel of niet) in beginsel niet kwalificeert als een per se hardcorebeperking in de zin van artikel 4 sub b en c van de Groepsvrijstelling Verticalen. Afhankelijk van de omstandigheden van het geval dient bekeken te worden of een dergelijk verbod al dan niet verenigbaar kan zijn met de mededingingsregels. $^{6}$

Selectieve distributieovereenkomsten zijn distributieovereenkomsten waarbij op basis van (1) kwalitatieve en/of (2) kwantitatieve criteria het aantal erkende distributeurs van en/of distributiecondities voor de verkoop van specifieke producten wordt beperkt en doorverkoop aan niet-erkende distributeurs kan worden verboden. Selectieve distributiesystemen vallen onder de Groepsvrijstelling Verticalen omdat bepaalde efficiëntieverbeteringen kunnen worden behaald die voordelen voor de consument kunnen opleveren. Zo zouden retailers bijvoorbeeld geselecteerd kunnen worden op basis van de kennis van een bepaald product (zodat consumenten beter worden geïformeerd), op basis van de atmosfeer die de retailer biedt (denk aan luxeproducten die worden gepresenteerd in een fijne winkel waar ruim de tijd wordt genomen voor klanten, eventueel onder het genot van een glaasje wijn), of op basis van een kwaliteitsgarantie (zodat de kwaliteit van het betreffende product overal hetzelfde is).

Bij kwalitatieve criteria kan gedacht worden aan eisen betreffende productkennis van het personeel, de winkelinrichting of het serviceniveau (denk aan de verplichte aanwezigheid van een opticien in een brillenwinkel, het vereiste van een fysiek verkooppunt - 'brick-andmortar' - waar klanten een product kunnen bekijken). Kwantitatieve criteria beperken het aantal distributeurs dat is toegestaan binnen één systeem. In de praktijk worden selectieve distributieovereenkomsten veelal gebruikt om de kwaliteit van een bepaald merk of product te waarborgen, met name door het beperken van de wederverkoop via kanalen die afbreuk kunnen doen aan de kwaliteit van hun merken en producten. Door de komst van het internet en de toename in de verkoop van (luxe)producten via het internet bevatten selectieve distributieovereenkomsten steeds vaker de brick-andmortar-verplichting.
Selectieve distributieovereenkomsten zijn niet in alle gevallen toegelaten onder het mededingingsrecht. Volgens de Europese Commissie zijn de mogelijke risico's voor de mededinging een vermindering van de concurrentie binnen een merk, de uitsluiting van een bepaald type of bepaalde typen distributeurs, afzwakking van de concurrentie en vergemakkelijking van collusie tussen leveranciers of afnemers. Deze risico's bestaan eens te meer in het geval van een cumulatief effect (met andere woorden de mate waarin de markt door soortgelijke overeenkomsten van anderen wordt bestreken). ${ }^{7}$

\section{Metro-criteria}

In het Metro-arrest ${ }^{8}$ formuleerde het Hof van Justitie criteria op grond waarvan bepaald kan worden of een selectief distributiesysteem in overeenstemming is met het mededingingsrecht; de zogeheten Metro-criteria (nu ook expliciet opgenomen in de Richtsnoeren Verticalen). ${ }^{9}$ Volgens het Hof van Justitie vormen selectieve distributieovereenkomsten waarbij het 30 procentmarktaandeel overschreden wordt, geen beperking van de mededinging in de zin van artikel 101 lid 1 VWEU indien aan de volgende drie criteria wordt voldaan:

1. Een systeem van selectieve distributie is noodzakelijk vanwege de eigenschappen van de betrokken producten.

2. Selectie van distributeurs vindt plaats op grond van objectieve kmalitatieve criteria die uniform/zonder discriminatie worden toegepast voor alle potentiële wederverkopers.

3. De vastgestelde criteria gaan niet verder dan noodzakelijk voor bescherming van de kwaliteit of het goed gebruik van het product. ${ }^{10}$

In $L^{\prime}$ Oreal ${ }^{11}$ geeft het Hof van Justitie vervolgens aan dat voor voldoening van de kwalitatieve Metro-criteria voor de selectie van wederverkopers ook moet worden onderzocht of de eigenschappen van het betrokken product:

'(...) voor het behoud van de kwaliteit en ter verzekering van het juiste gebruik ervan, tot een selectief distributiestelsel dmingen en of aan deze doelstellingen niet reeds is voldaan door een nationale regeling inzake de toegang tot het beroep van wederverkoper of inzake de verkoopvoorwaarden voor het betrokken produkt. (...)'12
7. Richtsnoeren inzake verticale beperkingen, par. 175.

8. HvJ EG 25 oktober 1977, zaak C-26/76, Metro/Commissie, ECLI:EU:C: 1977:167.

9. Richtsnoeren inzake verticale beperkingen, par. 175

10. Metro, r.o. 20-21

11. HvJ EG11 december 1980, zaak C-31/80, L'Oreal/De Nieuwe AMCK, ECLI:EU:C:1980:289.

12. L'Oreal, r.o. 16 , cursivering auteurs. 
Het Hof van Justitie geeft ook hier aan dat moet worden nagegaan of de toegepaste criteria niet strenger zijn dan nodig.

Verbod op verkoop via onlinemarktplaatsen als selectiecriterium

Via onlinemarktplaatsen (denk aan eBay en marktplaats. $n l$ ) worden verschillende categorieën producten op één en dezelfde website aangeboden. Zo worden bijvoorbeeld boeken naast kleding, juwelen en luiers verkocht. Voor fabrikanten van luxeproducten bestaat daardoor de angst dat verkoop via deze onlinemarktplaatsen kan leiden tot afbreuk van de kwaliteit van hun luxeproduct of -merk. Zo zou de verkoop van een Patek Phillipe-horloge naast een skippybal, Nijntje-trui, pak Pampers luiers of een Mickey Mouse-horloge de indruk kunnen wekken dat een Patek Phillipe-horloge ook niet bijster exclusief is. Het is daarom niet ongebruikelijk dat de fabrikanten/rechthebbenden van dergelijke luxemerken en -producten de wederverkoop via (niet-erkende) onlinemarktplaatsen trachten te verbieden. Zoals eerder opgemerkt, volgens de Commissie leggen fabrikanten zelfs steeds meer beperkingen op ten aanzien van verkoop via het internet.

Pierre Fabre verbiedt alle online verkoop.

Dat gaat te ver!

Al in 2011 buigt het Hof van Justitie zich in het Pierre Fabre-arrest ${ }^{13}$ over de vraag of een algeheel verbod op wederverkoop via (online) marktplaatsen door middel van een selectieve distributieovereenkomst in overeenstemming is met het mededingingsrecht. Pierre Fabre hanteerde een selectief distributiestelsel op grond waarvan de betreffende cosmeticaproducten uitsluitend fysiek in een winkel mochten worden verkocht - dus niet online. Het Hof van Justitie oordeelde dat een absoluut verbod op onlineverkoop in het algemeen niet mededingingsrechtelijk toelaatbaar is. Volgens het Hof van Justitie kwalificeert een dergelijke beperking als een mededingingsrechtelijk ontoelaatbaar strekkingsbeding. Het Hof van Justitie oordeelde dat:

'artikel 101, lid 1, VWEU aldus moet worden uitgelegd dat een (...) selectief distributiestelsel vereist dat de verkoop van cosmetica en lichaamsverzorgingsproducten plaatsvindt in een fysieke ruimte waarin een gediplomeerde apotheker aanwezig moet zijn, met als gevolg dat het gebruik van het internet voor die verkopen verboden is, de strekking heeft de mededinging te beperken in de zin van die bepaling, indien, na een individueel en concreet onderzoek van de bewoordingen en het oogmerk van deze contractbepaling en de juridische en economische context waarbinnen zij moet worden geplaatst, naar voren komt dat deze contractbepaling, gelet op de eigenschappen van de betrokken producten, niet objectief gerechtvaardigd is. ${ }^{14}$

13. HvJ EU 13 oktober 2011, zaak C-439/09, Pierre Fabre, ECLI:EU:C: 2011:649.

14. Pierre Fabre, r.o. 47
Het verbod op onlineverkoop leidt ertoe dat erkende distributeurs geen producten op afstand kunnen verkopen. Dit zorgt voor een aanzienlijke beperking van de mogelijkheden tot verkoop buiten een relevant activiteitengebied. Het Hof van Justitie stelde vervolgens door toepassing van de Metro-criteria vast dat de wederverkopers weliswaar worden gekozen op basis van objectieve criteria, maar dat de doelstelling van het in stand houden van het luxe-imago van de producten geen rechtvaardiging kan zijn van een (totaal)verbod op onlineverkoop. ${ }^{15} \mathrm{Er}$ is dus niet aan het derde Metro-criterium voldaan; het verbod gaat verder dan noodzakelijk voor bescherming van de kwaliteit of het goed gebruik van het product.

Naar aanleiding van het Pierre Fabre-arrest wordt in principe aangenomen dat het zeer moeilijk is (of zelfs praktisch onmogelijk) een mededingingsrechtelijk toelaatbaar totaalverbod op onlineverkoop (waaronder dus ook verkoop via onlinemarktplaatsen) via een selectief distributiestelsel af te dwingen. De vraag die vervolgens opkomt, is of een gedeeltelijk verbod op onlineverkoop wel toelaatbaar is onder het mededingingsrecht (bijvoorbeeld uitsluitend een verbod op onlinemarktplaatsen of niet erkende onlinewederverkoop). Deze vraag was het onderwerp van de Coty-zaak.

\section{Coty: de gulden middenweg?}

Op 6 december 2017 oordeelt het Hof van Justitie in de Coty-zaak dat een gedeeltelijke beperking van internetverkoop in overeenstemming kan zijn met het mededingingsrecht wanneer dit gerechtvaardigd is ter bescherming van het luxe-imago van de producten in kwestie. ${ }^{16}$

\section{Feiten}

Coty is een leverancier van luxeproducten (cosmetica) in Duitsland en verkoopt en promoot haar merkproducten als luxeproducten van de hoogste kwaliteit. In de selectieve-distributieovereenkomsten die Coty sluit met haar distributeurs staat dat elk fysiek verkooppunt door Coty moet zijn erkend en dat daar bepaalde eisen voor gelden (met betrekking tot de luxe uitstraling). Zo moeten de inrichting van het betreffende verkooppunt, het productaanbod, de reclame en de verkooppresentatie het luxekarakter van de Coty producten en merken onderstrepen en ondersteunen. Daarnaast geldt een aanvullende overeenkomst ten aanzien van internetverkoop waarin wordt bepaald dat het bij internetverkoop niet is toegestaan een andere naam te gebruiken of een derde, niet-erkende, onderneming in te schakelen. $\mathrm{Na}$ inwerkingtreding van de Groepsvrijstelling Verticalen besluit Coty de overeenkomsten te wijzigen en de verplichtingen onder de aanvullende overeenkomst ten aanzien van internetverkoop uit te breiden. Onder de nieuwe voorwaarden zou de distributeur enkel het recht hebben Coty's producten via het internet te verkopen, als dit in

15. Pierre Fabre, r.o. 38-46.

16. Coty. 
een 'elektronische etalage' van een erkende winkel plaatsvindt waarbij het luxekarakter van de producten onaangetast blijft. Dit komt in feite neer op een verbod op verkoop via open internetmarktplaatsen.

Parfumerie Akzente is aangesloten bij het distributienetwerk van Coty maar is het niet met deze aanpassing eens. Akzente weigert met deze wijzigingen in te stemmen en start vervolgens een procedure bij de nationale rechter. Uiteindelijk stelt het Oberlandesgericht Frankfurt am Main (de hogere regionale rechter in Frankfurt am Main) in deze zaak vier prejudiciële vragen aan het Hof van Justitie.

Antwoord op eerste vraag

Met de eerste vraag vraagt de nationale rechter feitelijk een bevestiging dat een selectief distributiestelsel betreffende luxecosmetica dat primair tot doel heeft het luxeimago van die producten in stand te houden in beginsel verenigbaar is met artikel $101 \mathrm{VWEU} .{ }^{17}$

Het Hof van Justitie benadrukt onder verwijzing naar bestaande rechtspraak in Pierre Fabre en Copad ${ }^{18}$ dat een selectief distributiestelsel op zichzelf het behoud van de kwaliteit en het juiste gebruik van luxeproducten kan waarborgen. Een selectief distributiestelsel kan bijdragen aan de reputatie van de betrokken producten en het behoud van de luxueuze uitstraling ervan. Volgens het Hof van Justitie kan een dergelijk selectief distributiestelsel ook noodzakelijk zijn voor het behoud van de kwaliteit en het juiste gebruik van de luxeproducten. ${ }^{19}$ Hierin volgt het Hof van Justitie de conclusie van advocaat-generaal Wahl, waarin hij aangeeft dat een algeheel verbod als in Pierre Fabre niet aan de orde is, en dat de beperking als opgelegd door Coty wel toelaatbaar is onder artikel 101 lid 1 VWEU, mits aan de Metro-criteria wordt voldaan. ${ }^{20}$ Het Hof van Justitie benadrukt in dit verband dat hoewel in Pierre Fabre is bepaald dat de instandhouding van het prestige-imago van die cosmetica en lichaamsverzorgingsproducten geen legitiem vereiste vormde ter rechtvaardiging van een absoluut verbod om die producten op internet te verkopen, hieruit niet volgt dat bescherming van het luxe-imago geen rechtvaardiging meer kan vormen voor een selectief distributienetwerk voor producten, waaronder in het bijzonder luxeproducten. ${ }^{21}$

Het antwoord op de eerste vraag luidt daarom dat artikel 101 VWEU niet in de weg staat aan een stelsel van selectieve distributie van luxeproducten dat primair tot doel heeft het luxe-imago van die producten in stand te houden. Hierbij geldt wel dat de wederverkopers moeten worden gekozen op grond van objectieve criteria van kwalitatieve aard die uniform worden vastgesteld voor alle potentiële wederverkopers en worden toegepast

17. Coty, r.o. 21

18. HvJ EG 23 april 2009, zaak C-59/08, Copad, ECLI:EU:C:2009:260; hieronder nader toegelicht.

19. Coty, r.o 22-35.

20. Conclusie van A-G Wahl van 26 juli 2017 in zaak C-230/16, Coty, ECLI:EU:C:2017:603, par. 59-93

21. Coty, r.o. $32-35$. zonder discriminatie en niet verder gaan dan noodzakelijk is. ${ }^{22}$

Het Hof van Justitie spreekt zich hierover niet met zoveel woorden uit, maar volgens advocaat-generaal Wahl gaat het er niet zozeer om of het luxekarakter van de producten door het selectieve distributiestelsel wordt gewaarborgd, maar of de eigenschappen van het product worden gewaarborgd:

'[...] het [gaat] erom de eigenschappen van de betrokken producten in stand te houden, ongeacht of die eigenschappen tot uitdrukking komen in de materiële kenmerken of in het luxueuze of prestigieuze imago van de artikelen. Selectieve distributie kan vanwege het mededingingsbevorderende effect dat zij heeft als legitiem worden beschouwd, of de producten in kwestie nu bepaalde materiële kenmerken hebben, zoals in het geval van kwalitatief hoogwaardige of technologisch geavanceerde producten, of met een luxe-imago worden geassocieerd. ${ }^{, 23}$

\section{Antwoord op tweede vraag}

Met de tweede vraag wil de nationale rechter begrijpen of artikel $101 \mathrm{VWEU}$ in de weg staat aan een contractueel beding dat de verkoop van luxeproducten via internetmarktplaatsen van derden verbiedt voor erkende wederverkopers van een selectief distributiestelsel. Volgens het Hof van Justitie staat artikel 101 lid 1 VWEU in beginsel niet aan een dergelijke contractuele beperking in de weg. ${ }^{24}$ Onder verwijzing naar de bestaande rechtspraak in L'Oreal en Copad brengt het Hof van Justitie allereerst in herinnering dat relevant is of het verbod in kwestie geschikt is ter bereiking van het nagestreefde doel. ${ }^{25}$

Vervolgens oordeelt het Hof van Justitie dat het verbod op onlineverkoop van de betreffende producten via platforms van derden een 'coherente' beperking is - met andere woorden, een toelaatbare beperking die geschikt is om het luxe- en prestige-imago van de luxeproducten in stand te houden. ${ }^{26}$ In dit verband acht het Hof van Justitie relevant dat het contractuele beding in deze zaak bedoeld is om het luxe- en prestige-imago van de betrokken producten in stand te houden en de fabrikant/leverancier niet de mogelijkheid heeft toe te zien op de voorwaarden waaronder zijn producten worden verkocht via platforms die geen deel uitmaken van het selectieve distributiestelsel. Dit zou tot een verslechtering van het luxe-imago van de producten kunnen leiden en daarmee de aard van de producten kunnen aantasten. Op onlinemarktplaatsen worden doorgaans allerlei producten aangeboden, waaronder ook (veel) nietluxeproducten. Dit draagt niet bij aan het luxe-imago van de betreffende producten. ${ }^{27}$ Advocaat-generaal Wahl weidt nog iets verder uit over dit punt:

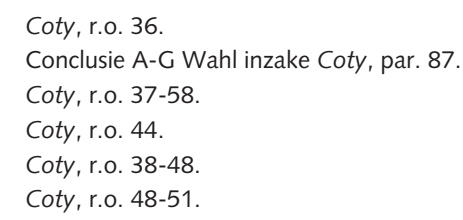


'niet alleen waarborgt het [verbod] dat die producten worden aangeboden in een omgeving die voldoet aan de kwaliteitsnormen van het hoofd van het distributienetwerk, maar ook biedt het bescherming tegen meeliftgedrag, doordat het voorkomt dat andere ondernemingen profiteren van de investeringen en inspanningen die de leverancier en andere erkende distributeurs hebben gedaan ter verbetering van de kwaliteit en het imago van de betrokken producten. ${ }^{28}$

De advocaat-generaal lijkt dus ook te benadrukken dat contracten bescherming mogen bieden tegen free riding, maar het Hof van Justitie laat zich hier verder niet over uit.

Als laatste benadrukt het Hof van Justitie nog dat een contractueel beding waarbij de distributeurs wordt toegestaan platforms van derden te gebruiken (mits aan een aantal criteria wordt voldaan), niet even effectief is als een algeheel onlinemarktplaatsverbod, omdat er in het eerste scenario geen contractuele verhouding bestaat tussen de leverancier van de luxeproducten en de platforms van derden. De leverancier kan de platforms dus niet dwingen aan de kwaliteitseisen te voldoen. ${ }^{29}$ Omdat de fabrikant (meestal) ook niet zelf contracteert met een dergelijke marktplaats kan deze geen directe controle uitoefenen op de manier waarop producten worden aangeboden.

\section{Antwoord op derde en vierde vraag}

Ten slotte behandelt het Hof van Justitie de derde en vierde vraag gezamenlijk; met deze vragen wil de nationale rechter in feite weten of, ingeval het beding zou worden angemerkt als een beperking van de mededinging in de zin van artikel 101 lid 1 VWEU, het betreffende beding alsnog op grond van artikel 101 lid 3 VWEU zou kunnen worden vrijgesteld van de mededingingsregels (mede in het licht van de Groepsvrijstelling Verticalen). In dit verband vraagt de nationale rechter zich af of de contractuele beperking in kwestie kwalificeert als een beperking van de klantenkring in de zin van artikel 4 sub b van de Groepsvrijstelling Verticalen en/of een beperking van de passieve verkoop aan de eindgebruiker in de zin van artikel 4 sub c van de Groepsvrijstelling Verticalen. Met andere woorden, de nationale rechter wil weten of de beperking in kwestie een hardcorebeperking is in de zin van de Groepsvrijstelling Verticalen. ${ }^{30}$

Volgens het Hof van Justitie blijkt niet dat Coty via het selectieve-distributiestelsel kan nagaan of eindgebruikers wel of niet via onlinemarktplaatsen aankopen doen. Daarnaast kunnen eindgebruikers nog steeds toegang krijgen tot het (volledige) internetaanbod van de erkende distributeurs met behulp van onlinezoekmachines. Het Hof van Justitie concludeert op die basis dat het selectieve-distributiesysteem van Coty niet tot beper-

28. Conclusie A-G Wahl inzake Coty, par. 106.

29. Coty, r.o. 52-58.

30. Coty, r.o. 59-62. king van klanten of passieve verkoop aan de eindgebruiker leidt. $^{31}$

Het Hof van Justitie concludeert op die basis - in lijn met wat advocaat-generaal Wahl hierover uitvoerig heeft beschreven ${ }^{32}$ - dat de beperkingen die door Coty worden opgelegd ten aanzien van verkoop via internetmarktplaatsen voor zover deze een inbreuk op artikel 101 lid 1 VWEU zou opleveren, niet als hardcorebeperking kwalificeren waardoor de Groepsvrijstelling Verticalen niet van toepassing zou zijn; het is geen beperking van de passieve verkoop van de erkende wederverkopers aan de eindgebruiker noch een beperking van de klantenkring van de wederverkopers. ${ }^{33}$

Het Hof van Justitie (en Wahl) gaat vervolgens echter niet in op de vraag of een dergelijk selectieve-distributiestelsel, indien het een inbreuk op artikel 101 lid 1 VWEU zou opleveren, eventueel zou kunnen worden vrijgesteld door toepassing van lid 3 van artikel 101 VWEU.

Inmiddels heeft het Gerechtshof Frankfurt in de bodemzaak arrest gewezen. Na toetsing aan de criteria die het Hof van Justitie in de Coty-zaak heeft neergelegd concludeert het Gerechtshof Frankfurt - in de lijn der verwachting - dat Coty's verbod op verkoop via online platforms van derden toegelaten is om het luxe-imago van de goederen te bewaren. ${ }^{34} \mathrm{Op}$ het moment van schrijven is er nog geen hoger beroep ingesteld tegen het arrest van het Gerechtshof Frankfurt.

Nationale rechtspraak

Tegelijk met de Coty-procedure lag een aantal vergelijkbare zaken voor bij de nationale rechter; de Nike-zaak in Nederland ${ }^{35}$ en de Asics-zaak in Duitsland. ${ }^{36}$

\section{- Het Nike-arrest}

Het Nike-arrest gaat, in het kort, om een geschil tussen Nike European Operations Netherlands (NEON), verantwoordelijk voor de distributie van Nike-producten in Europa, en Action Sport, een retailer met fysieke winkel op Sicilië (Italië). Action Sport mag volgens de voorwaarden van haar overeenkomst met NEON geen Nikeproducten verkopen via niet-geautoriseerde webshops. Action Sport biedt desalniettemin Nike-producten aan via niet-geautoriseerde webshops zoals Amazon. NEON ontbindt vervolgens de overeenkomst met Action Sport en verbiedt Action Sport de toegang tot haar webplatform, zodat Action Sport niet langer bestellingen bij NEON kan plaatsen. Nog voordat het Hof van Justitie arrest wijst in Coty, oordeelt de Rechtbank Amsterdam - mede op grond van de conclusie van advocaat-generaal

\footnotetext{
1. Coty, r.o. 63-68.

Conclusie A-G Wahl inzake Coty, par. 123-156

Coty, r.o. 69

4. Zie het persbericht https://ordentliche-gerichtsbarkeit.hessen.de/ pressemitteilungen/luxusprodukte-rechtfertigen-vertriebsverbot-aufamazonde.

35. Rb. Amsterdam van 4 oktober 2017, ECLI:NL:RBAMS:2017:7282 (Nike).

36. Bundesgerichtshof van 12 december 2017, ECLI:DE:BGH:2017: 121217BKVZ41.17.0 (Asics)
} 
Wahl in Coty - dat de beperking niet tot een inbreuk op het mededingingsrecht leidt.

Met verwijzing naar het Metro-arrest oordeelt de Rechtbank Amsterdam dat het selectieve-distributiecriterium voldoet aan de eisen van objectiviteit, uniformiteit en non-discriminatie. De rechtbank baseert zich vervolgens ook uitdrukkelijk op de conclusie van advocaat-generaal Wahl in Coty ${ }^{37}$ om tot de conclusie te komen dat de Nike-producten moeten worden aangemerkt als luxeproducten en dat het selectieve-distributiecriterium is bedoeld om het ' $(. .$.$) merkimago in stand te houden' { }^{38}$ Ook voor het antwoord op de vraag of het selectieve-distributiecriterium noodzakelijk is voor de instandhouding van het luxe-imago van de producten verwijst de Rechtbank Amsterdam naar de conclusie van de advocaat-generaal in Coty. De rechtbank concludeert dat het selectieve-distributiecriterium een '(..) onder artikel 101 lid 1 VWEU toelaatbaar selectief distributiesysteem is, [dat] niet nietig is en NEON bevoegd is Action Sport daar aan te houden'. ${ }^{39}$ De Rechtbank Amsterdam ziet dan ook geen aanleiding om de zaak aan te houden totdat het Hof van Justitie arrest wijst in Coty. De rechtbank voegt hieraan toe:

'Amazon is geen geautoriseerde (r)etailer zodat aan NEON geen middelen tot handhaving van haar selectieve distributiesysteem jegens Amazon ter beschikking staan. Het staat Amazon uiteraard vrij om bij NEON een verzoek te doen om tot het selectieve distributiesysteem te worden toegelaten en NEON zal, indien Amazon aan de criteria voldoet, gehouden zijn om Amazon als zodanig te aanvaarden, maar zolang Amazon niet de status heeft van geautoriseerde retailer valt zij buiten het systeem. ${ }^{40}$

Met haar uitspraak in het Nike-arrest liep de Rechtbank Amsterdam eigenlijk vooruit op de uitspraak van het Hof van Justitie in Coty. Op grond van (een liberale interpretatie van) de definitie van luxemerk - is Nike namelijk wel een luxemerk? De rechtbank besteedt hier in ieder geval geen overwegingen aan - en op basis van het belang van het in stand houden van dat luxemerk, oordeelt de rechtbank het selectieve-distributiecriterium toelaatbaar onder artikel 101 lid 1 VWEU. Daarnaast lijkt de rechtbank waarde te hechten aan de contractsvrijheid van partijen en de civielrechtelijke consequenties van de overeenkomst. Met andere woorden, NEON en Action Sport zijn een overeenkomst aangegaan en dienen zich daaraan te houden. Hieronder valt ook het feit dat Action Sport de Nike-producten niet via nietgeautoriseerde retailers mag verkopen, of dat nou offline of online is. De uitspraak van de Rechtbank Amsterdam lijkt ook niet anders te zijn geweest indien zij had

O.a. op par. 74 uit de conclusie waarin wordt aangegeven dat ' (...) luxe producten, gelet op de kernmerken en de aard ervan, de toepassing van een selectief distributiestelsel noodzakelijk kunnen maken om het behoud van de kwaliteit en het juiste gebruik van die producten te verzekeren. (...)'

38. Nike, r.o. 4.9 .3

39. Nike, r.o. 4.10.

40. Nike, r.o. 4.11 gewacht op de uitspraak van het Hof van Justitie in Coty. Het Hof van Justitie geeft immers nog minder inzicht in wat als een luxeproduct zou moeten kwalificeren dan de advocaat-generaal, terwijl dit van doorslaggevend belang lijkt te zijn geweest voor de Rechtbank Amsterdam.

\section{- Het Asics-arrest}

De Duitse rechter lijkt een hogere kwaliteitseis te stellen aan luxeproducten en oordeelt na de Coty-uitspraak kort gezegd dat Asics-schoenen geen luxeproducten zijn en dat het merk Asics geen kwaliteitsbescherming verdient. In het Asics-arrest concludeert het Duitse Bundesgerichthof namelijk dat een totaalverbod op het gebruik van prijsvergelijkingsmachines in een selectief distributiestelsel, zoals door Asics gehanteerd, een hardcorebeperking is in de zin van de Groepsvrijstelling Verticalen.

Anders dan in Pierre Fabre betreft deze restrictie geen per se verbod op onlineverkoop. Het Bundesgerichthof is desondanks van mening dat de beperking ten minste als beperking van passieve verkoop en daarmee als een hardcorerestrictie in de zin van artikel 4 sub c van de Groepsvrijstelling Verticalen moet worden aangemerkt. In dit verband merkt het Bundesgerichthof op dat (1) het verbod niet gericht is op luxegoederen, (2) tegenwoordig zoveel producten online verkocht worden, met zoveel verschillende prijzen, leveranciers en voorwaarden dat prijsvergelijkingsmachines van cruciaal belang zijn voor consumenten, en (3) dat dit verbod wordt gecombineerd met een verbod voor wederverkopers via een website van derden reclame te maken en/of een doorklikmogelijkheid te verschaffen voor de eigen website. $^{41}$

Gezien deze overwegingen zou het Bundesgerichthof als het verbod zich beperkt tot wat volgens hem wel 'daadwerkelijke' luxeproducten zijn, in lijn met het Cotyarrest geoordeeld kunnen hebben dat ter bewaking van het luxekarakter van de producten een verbod op nietgeautoriseerde prijsvergelijkingsmachines is toegestaan.

\section{Onduidelijkheden na Coty (en nationale rechtspraak)}

Coty verschaft op een aantal vlakken duidelijkheid, maar er blijft onduidelijkheid bestaan of vanuit mededingingsrechtelijk perspectief een totalverbod op verkoop via onlinemarktplaatsen toelaatbaar kan zijn en wanneer een product als luxeproduct kan kwalificeren. Uit de arresten Nike en Asics blijkt des te meer hoe belangrijk de kwalificatie als luxeproduct is voor deze vraag en voor de eenheid van rechtspraak op dit punt in Europa.

Wat is een luxeproduct?

Om met het laatste punt te beginnen, het begrip luxeproduct is wellicht lastig in objectieve criteria te vatten. 
Wat voor de één als luxehorloge wordt aangemerkt kan door een ander als alledaags gebruiksvoorwerp worden gezien, afhankelijk van factoren als cultuur, leeftijd, inkomen, geslacht enzovoort. In het Copad-arrest lijkt het Hof van Justitie wel een poging gedaan te hebben dit begrip verder te definiëren. ${ }^{42}$ In Copad neemt het Hof van Justitie de kwaliteit van de producten als uitgangspunt, en geeft aan dat deze kan voortvloeien uit de materiële kenmerken van het betreffende product, evenals de allure en het prestigieuze imago die de producten een luxueuze uitstraling geven. Die uitstraling is een essentiële eigenschap van de producten omdat de consument ze daardoor kan onderscheiden van andere soortgelijke producten. De aantasting van een dergelijke luxueuze uitstraling wordt dus ook beschouwd als afbreuk doende aan de kwaliteit van het product in kwestie. $^{43}$

Het lijkt er dus in de kern om te gaan hoe een product wordt gepresenteerd. Wordt het product als exclusief, duur en luxe gepresenteerd? Waar het om gaat, is dat de consument begrijpt en vindt dat het betreffende product een luxeproduct is. Het interessante hieraan is dat er dus altijd een element van subjectiviteit aan luxeproducten blijft kleven. Er zal immers altijd discussie blijven bestaan over dit punt. Zo beargumenteert Pierre Fabre ook dat haar cosmeticaproducten luxeproducten zijn en het verbod op onlineverkoop noodzakelijk is om 'het prestigieuze imago van de betrokken producten in stand te houden.' (en is niet uitgesloten dat een minder vergaand verbod wel toegestaan zou zijn geweest). ${ }^{44}$

De hierboven beschreven definitie van luxeproduct volgens Copad vereist niet alleen een analyse op basis van objectieve producteigenschappen, maar kan ook gebaseerd zijn op consumentenopvattingen. Zo kan worden gekeken naar reclamecampagnes (worden deze gezien als prestigieus of doen deze juist af aan de luxueuze uitstraling?), het gebruik van bepaalde geuren of kleuren (zorgt dit voor een luxe en prestigieuze allure?) en de prijsstelling van de desbetreffende producten (in Japan is men bereid \$ 402 voor een fles water van $750 \mathrm{ml}$ te betalen van het merk Kona Nigari - en dat is niet eens de duurste fles water ter wereld). Het lijkt daarom vanzelfsprekend dat een Patek Phillipe-horloge, bekend om zijn hoogwaardige kwaliteit, allure en hoge prijs, als luxeproduct wordt gezien. Ook lijkt het vanzelfsprekend dat een Mickey Mouse-horloge, bekend als voornamelijk kinderartikel en gemaakt van goedkoop materiaal, geen luxeproduct is. Maar het is lastiger te bepalen in welke categorie een Swatch-horloge valt (ook tussen de auteurs van dit artikel zijn de meningen verdeeld). Het Nike- en het Asics-arrest laten zien dat ook sportmerken door de een als een luxemerk beschouwd zullen worden en door de ander als onvoldoende luxe om 'beschermd' te worden.
Verbod op onlinemarktplaatsen voor poespas Een andere vraag die Coty onbeantwoord laat, is of een verbod op de verkoop via onlinemarktplaatsen van derden ook kan zijn toegestaan als de desbetreffende producten geen luxeproducten zijn. De uitspraak van het Bundesgerichtshof lijkt te suggereren dat Coty zich specifiek op luxegoederen richt. Wij denken echter dat het Hof van Justitie ook ruimte laat voor het opleggen van een verbod op de verkoop via onlinemarktplaatsen van derden voor 'normale' producten. Ook Wahl gaf op 7 september 2018 aan dat wat hem betreft het arrest niet is beperkt tot luxegoederen. ${ }^{45}$

Het Hof van Justitie lijkt te oordelen dat een marktplaatsverbod ongeacht het karakter van het product geen hardcorebeperking oplevert. Het Hof van Justitie acht immers doorslaggevend of aan de Metro-criteria wordt voldaan - c.q. dat het verbod niet verder gaat dan noodzakelijk (zonder dat die noodzakelijkheid per se in het luxekarakter van de betreffende producten moet worden gevonden). Het Hof van Justitie zegt namelijk in antwoord op de tweede vraag in Coty dat '(...) onder voorbehoud van de door de verwijzende rechterlijke instantie te verrichten verificaties, een dergelijk verbod verenigbaar is met artikel 101, lid 1, VWEU'. ${ }^{46}$

Het Hof van Justitie lijkt daarmee te suggereren dat indien de opgelegde beperking niet evenredig en proportioneel is, deze (mogelijk) wel inbreuk makt op artikel 101 lid 1 VWEU, maar dat dit geen hardcorerestrictie is. In dat geval kan de Groepsvrijstelling Verticalen nog een mogelijke uitweg bieden zolang de marktaandelen van partijen onder de 30 procent blijven. Met andere woorden, de rechtspraak van het Hof van Justitie toont aan dat het verbod op de verkoop van producten op onlinemarktplaatsen geen beperking van artikel 101 lid 1 VWEU oplevert indien aan de Metro-criteria wordt voldaan. Indien niet aan de Metro-criteria wordt voldaan, kunnen partijen bij een selectieve distributieovereenkomst nog steeds zelf nagaan of de beperking uitgezonderd kan worden van de toepassing van artikel 101 lid 1 VWEU via de Groepsvrijstelling Verticalen.

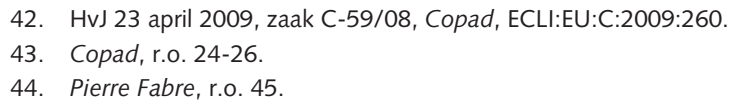

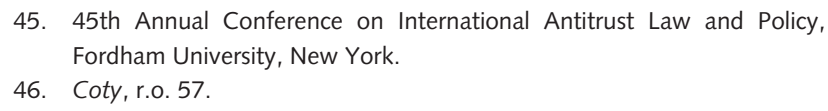

